\title{
FORMULASI EMULSI ORAL MINYAK JINTAN HITAM (Nigella sativa) DENGAN BAHAN PENGENTAL
}

\author{
M. Ilham Tomagola \\ Fakultas Farmasi Universitas Muslim Indonesia \\ Email : tomagolailham@gmail.com
}

\begin{abstract}
The aim of this research was to determine the type and thickening agent variation which of result stable emulsion. There were three thickening agent, they are CMC sodium, Acacia gum and xanthan gum used in formula. Those three formula then evaluated by accelarated condition method by which the parameter were organoleptic, type of emulsion, creaming volumen, viscosity and type of flow, dispersed globule observation before and after the condition. Organoleptic result showed that there were nothing different in formula II. Type of emulsion showed that those three formula were $\mathrm{o} / \mathrm{m}$ emulsion. There were nothing creaming volume in formula I and II. Statistic analyze in viscosity measurement and yield value, rheogram curve showed close each other, dispersed globule there were not undergo aggrregation in formula I and II before ad after accelarated condition. Of those parameter the conclusión was formula II is stable one.
\end{abstract}

Key word : Formulation, Emulsion, Nigella sativa, Agent Variation

\section{PENDAHULUAN}

Di Arab, jintan hitam dikenal sebagai habbatus sauda (biji yang menyenangkan) atau habbatul baraka, artinya biji yang membawa berkah. Bagi kaum muslim, jintan hitam merupakan anugerah Allah. Anjuran Nabi Muhammad SAW untuk memanfaatkan jintan hitam tercatat dalam sebuah hadis." Tetaplah berobat dengan Habbatus sauda karena sesungguhnya ia bisa mengobati semua penyakit, kecuali kematian".

Tahun 1960, Mahfouz dan Badr El-Dakhakhny, peneliti Mesir, mengisolasi zat aktif Nigellone dari minyak atsiri jintan hitam. Peneliti menemukan, dua minyak volatil (cenderung menguap pada suhu dan tekanan normal) dalam jintan hitam adalah Nigellone dan Thymoquinone.

$\mathrm{Di}$ tahun yang sama ElDakhakhny melaporkan bahwa minyak jintan hitam memiliki kemampuan meredakan radang sendi. Penelitian di laboratorium mengungkapkan kandungan minyak Nigellone dan Thymoquinone dalam jintan hitam bersifat antileukimia. Penelitian lainnya, kedua unsur itu membantu 
meningkatkan sistem kekebalan tubuh dan efektif untuk mengobati asma dan batuk kering.

Prof. G Reitmuller, Direktur Institut Immonologi dari Universitas Munich mengakui minyak jintan hitam dapat dijadikan obat untuk penyakit yang menyerang kekebalan tubuh seperti kanker dan AIDS. Pada kongres kanker internasional di New Delhi, minyak jintan hitam diperkenalkan ilmuan kanker Immono Biology Laboratory, dari California Selatan. "Nigella sativa dapat merangsang sumsum tulang dan selsel kekebalan. Interferon-nya menghasilkan sel-sel normal terhadap virus yang merusak sekaligus menghancurkan sel-sel tumor dan meningkatkan antibodi. Dr. Med. Peter Schleincher, ahli immonologi dari Universitas Munich ia melakukan pengujian terhadap 600 orang yang menderita alergi. Hasilnya cukup meyakinkan, $70 \%$ yang menderita alergi terhadap debu, serbuk, jerawat, dan asma sembuh setelah diberi minyak Nigella (jintan hitam). Dalam praktiknya, DR. Schleincher memberi resep Nigella ke pasiennya yang menderita influenza. Jadi jintan hitam bisa digunakan sebagai anti histamine.

Minyak jintan mempunyai rasa yang kurang menyenangkan, dan pengolahan lebih lanjut untuk menutupi rasa yang kurang menyenangkan tersebut, salah satunya adalah dengan membuat emulsi minyak jintan hitam. Emulsi yang digunakan dalam bidang farmasi adalah suatu sediaan yang mengandung dua cairan yang tidak saling bercampur, dimana salah satu cairan terdispersi secara seragam sebagai globul-globul kedalam cairan lainnya.

Selain emulgator, bahan yang digunakan untuk menstabilkan emulsi adalah bahan pengental. Bahan pengental yang biasa digunakan dalam pembuatan emulsi oral adalah Na. CMC, gum arab, gum xanthan dan lain-lain. Pemilihan bahan pengental ini didasarkan pada keamanannya jika digunakan dalam sediaan oral.

\section{METODE PENELITIAN}

\section{Alat dan bahan yang digunakan}

Lemari es, mantel pemanas, mikser, mikroskop foto, neraca, viskometer brookfield, volmeter dan termometer.

Bahan-bahan yang digunakan dalam penelitian yaitu minyak jintan hitam (Nigella sativa), aquadest, alfa tokoferol, gum arab, gum xanthan, metil paraben, Na. CMC, pasta pandan , propil paraben, span 80, sukrosa dan tween 80. 
Prosedur Kerja

Rancangan Formula

Dilakukan penelitian dengan menggunakan bahan-bahan sebagai berikut : minyak jintan hitam (Nigella sativa) sebagai bahan aktif, aquadest sebagai pelarut, alfa tokoferol sebagai antioksidan, metil paraben dan propil paraben sebagai pengawet, tween 80 dan span 80 sebagai emulgator, $\mathrm{Na}$ CMC, gum arab dan gum xanthan sebagai bahan pengental, pasta pandan sebagai pewarna dan pengaroma, dan sukrosa sebagai pemanis.

\section{Pembuatan Emulsi minyak jintan hitam}

Formula dengan bahan pengental Na. CMC

Dipisahkan antara fase minyak dan fase air. Dimasukan 40 gram sukrosa dalam 38,8 $\mathrm{ml}$ air dan dipanaskan hingga larut. Setelah itu dimasukan Na. CMC dengan sebanyak 8 gram dan diaduk hingga mengental. Kemudian dimasukan tween 80 dan metil paraben (bahan A). Pada saat yang bersamaan, dipanaskan span 80, minyak jintan hitam, alfa tokoferol dan propil paraben dalam gelas kimia pada suhu $70^{\circ} \mathrm{C}$ (bahan B). Setelah itu bahan B dimasukan kedalam bahan $A$ sambil diaduk dengan mikser, sampai terbentuk emulsi yang sempurna. Setelah itu ditambahkan pasta pandan dan diaduk kembali dengan mikser sampai dingin. Selama pengadukan dengan mikser, dilakukan metode pengadukan intermittent shaking (pengadukan berselang).

Formula dengan bahan pengental gum Arab

Dipisahkan antara fase minyak dan fase air. Dimasukan 40 gram sukrosa dalam 28,8 $\mathrm{ml}$ air dan dipanaskan hingga larut. Setelah itu dimasukan gum arab dengan sebanyak 18 gram dan diaduk hingga mengental. Kemudian dimasukan tween 80 dan metil paraben (bahan A). Pada saat yang bersamaan, dipanaskan span 80, minyak jintan hitam, alfa tokoferol dan propil paraben dalam gelas kimia pada suhu $70^{\circ} \mathrm{C}$ (bahan B). Setelah itu bahan B dimasukan kedalam bahan $A$ sambil diaduk dengan mikser, sampai terbentuk emulsi yang sempurna. Setelah itu ditambahkan pasta pandan dan diaduk kembali dengan mikser sampai dingin. Selama pengadukan dengan mikser, dilakukan metode pengadukan intermittent shaking (pengadukan berselang). 
Formula dengan bahan pengental gum xanthan

Dipisahkan antara fase minyak dan fase air. Dimasukan 40 gram sukrosa dalam 46,6 $\mathrm{ml}$ air dan dipanaskan hingga larut. Setelah itu dimasukan gum arab dengan sebanyak 0,18 gram dan diaduk hingga mengental. Kemudian dimasukan tween 80 dan metil paraben (bahan A). Pada saat yang bersamaan, dipanaskan span 80 , minyak jintan hitam, alfa tokoferol dan propil paraben dalam gelas kimia pada suhu $70^{\circ} \mathrm{C}$ (bahan B). Setelah itu bahan $B$ dimasukan kedalam bahan A sambil diaduk dengan mikser, sampai terbentuk emulsi yang sempurna. Setelah itu ditambahkan pasta pandan dan diaduk kembali dengan mikser sampai dingin. Selama pengadukan dengan mikser, dilakukan metode pengadukan intermittent shaking (pengadukan berselang).

\section{Evaluasi Kestabilan Emulsi}

Evaluasi kestabilan emulsi dilakukan sebelum dan sesudah penyimpanan dipercepat pada suhu $5^{\circ} \mathrm{C}$ dan $35^{\circ} \mathrm{C}$ secara bergantian masing - masing 12 jam selama 10 kali siklus.

\section{Pemeriksaan Organoleptis}

Organoleptis meliputi warna, konsistensi dan bau sediaan emulsi yang dilakukan sebelum dan setelah penyimpanan dipercepat.

\section{Pengujian Tipe Emulsi}

Penentuan dilakukan terhadap emulsi sebelum dan sesudah kondisi dipakasakan. Penentuan tipe emulsi dengan menggunakan metode hantaran listrik, yaitu sampel emulsi yang telah dibuat dimasukan sebanyak $25 \mathrm{ml}$ kedalam wadah kemudian diuji daya hantarnya dengan voltmeter. Apabila jarum bergerak maka tipe emulsi adalah m/a, dan sebaliknya apabila jarum tidak bergerak maka tipe emulsi yang terbentuk adalah $\mathrm{a} / \mathrm{m}$.

\section{Penentuan volume kriming}

Emulsi sebanyak $50 \mathrm{ml}$ ditempatkan dalam gelas ukur dan ditutup kemudian disimpan pada kondisi dipaksakan yaitu suhu $5^{\circ} \mathrm{C}$ dan $35^{\circ} \mathrm{C}$ secara bergantian masingmasing 12 jam. Kemudian diamati volume kriming yang terbentuk setiap satu siklus hingga siklus ke sepuluh.

Pengukuran viskositas dan tipe aliran emulsi

Pengukuran viskositas sediaan emulsi dilakukan sebelum dan setelah penyimpanan dipercepat. Pengukuran dilakukan dengan menggunakan Viskometer Brookfield, spindle no. 64 dengan kecepatan 50 putaran per menit (rpm). Sedangkan penentuan tipe aliran emulsi dilakukan dengan 
mengukur viskositas sediaan pada berbagai kecepatan yaitu 2, 5, 10, 20, 30, 50 dan $100 \mathrm{rpm}$. Kemudian dari data tersebut dihitung kecepatan geser dan tekanan geser. Kecepatan geser dan tekanan geser diplotkan membentuk rheogram untuk mengetahui tipe aliran yang terbentuk.

\section{Pengamatan tetes terdispersi}

Dilakukan sebelum dan setelah penyimpanan dipercepat. Pengamatan dilakukan dengan meneteskan emulsi pada objek gelas, kemudian ditutup dengan deck gelas. Setelah itu diamati dengan menggunakan mikroskop dengan perbesaran $40 \times 10$.

\section{HASIL PENELITIAN}

\section{Pemeriksaan organoleptis}

\begin{tabular}{llll}
\hline \multirow{2}{*}{ Jenis Bahan Pengental } & \multirow{2}{*}{ Jenis Pemeriksaan } & \multicolumn{2}{c}{ Kondisi } \\
\cline { 3 - 4 } Formula I & Bau & Sebelum & \multicolumn{1}{c}{ Sesudah } \\
& Warna & Khas aromatis & Khas aromatis \\
& Konsistensi & Hijau Tua & Hijau kecoklatan \\
& Bau & Kental & Kental \\
\hline \multirow{2}{*}{ Formula II } & Warna & Khas aromatis & Khas aromatis \\
& Konsistensi & Hijau Muda & Hijau muda \\
& Bau & Kental & Kental \\
\hline \multirow{2}{*}{ Formula III } & Warna & Khas aromatis & Khas aromatis \\
& Konsistensi & Hijau & Hijau dan coklat \\
& & Kental & Kental \\
\hline
\end{tabular}

\section{Penentuan volume kriming}

\begin{tabular}{cccc}
\hline Kondisi & Formula I & Formula II & Formula III \\
\hline Sebelum & Tidak ada & Tidak ada & Tidak ada \\
Sesudah & Tidak ada & Tidak ada & Ada \\
\hline
\end{tabular}

3. Penentuan tipe emulsi

\begin{tabular}{cccc}
\hline Kondisi & Formula I & Formula II & Formula III \\
\hline Sebelum & + & + & + \\
Sesudah & + & + & + \\
\hline
\end{tabular}

\section{Pengukuran viskositas dan tipe aliran}

Hasil pengukuran viskositas pada emulsi dengan bahan pengental gum arab, Na. CMC dan gum xanthan menggunakan Viskometer Brookfield pada kecepatan $50 \mathrm{rpm}$ dengan menggunakan spidel nomor 64, menunjukan viskositas rata-rata sediaan emulsi minyak jintan hitam sebelum dan sesudah penyimpanan dipercepat, yaitu :

\begin{tabular}{cccc}
\hline Kondisi & Formula I & Formula II & Formula III \\
\hline Sebelum & 55,733 & 50 & 54.133 \\
Sesudah & 59,067 & 52,033 & 50.4 \\
\hline
\end{tabular}


Sedangkan tipe aliran yang terbentuk ialah plastis yang memiliki nilai yield rata-rata sediaan emulsi minyak jintan hitam sebelum dan sesudah penyimpanan dipercepat yaitu :

\begin{tabular}{cccc}
\hline Kondisi & Formula I & Formula II & Formula III \\
\hline Sebelum & 2,857 & 2,424 & 5,557 \\
Sesudah & 4,840 & 4,608 & 4,805 \\
\hline
\end{tabular}

Keterangan :

Formula I = Bahan Pengental Gum Arab

Formula II = Bahan Pengental Gum Xanthan

Formula III = Bahan Pengental Na. CMC

PEMBAHASAN

Emulsi yang digunakan dalam bidang farmasi adalah suatu sediaan yang mengandung dua cairan yang tidak saling bercampur, biasanya minyak dan air dimana salah satu cairan terdispersi secara seragam sebagai globul-globul kedalam cairan lainnya.

Penelitian ini dilakukan berdasarkan pada pernyataan yang dikemukakan oleh Martin yaitu "kemungkinan besar yang diperlukan untuk mendorong terjadinya kestabilan adalah viskositas optimum bukan viskositas yang tinggi" (Martin, 1993). Martin juga mengatakan bahwa "Emulsi yang kental mungkin lebih stabil dari emulsi encer, lantaran terjadinya hambatan flokulasi dan penggabungan". Berdasarkan hal tersebut timbul suatu pemikiran bahwa selain emulgator sebagai bahan penstabil suatu emulsi, ternyata viskositas juga mempunyai peranan dalam menstabilkan emulsi. Pada penelitian ini dibuat emulsi oral dari minyak jintan hitam yang digunakan untuk memperkuat sistem imun. Prof. G Reitmuller, Direktur Institut Immonologi dari Universitas Munich mengakui minyak jintan hitam dapat dijadikan obat untuk penyakit yang menyerang kekebalan tubuh seperti kanker dan AIDS. Pada kongres kanker internasional di New Delhi, minyak jintan hitam diperkenalkan ilmuan kanker Immono Biology Laboratory, dari California Selatan. "Nigella sativa dapat merangsang sumsum tulang dan sel-sel kekebalan. Interferon-nya menghasilkan sel-sel normal terhadap virus yang merusak sekaligus menghancurkan sel-sel tumor dan meningkatkan antibodi. Dr. Med. Peter Schleincher, ahli immonologi dari Universitas Munich ia melakukan pengujian terhadap 600 orang yang menderita alergi. Hasilnya cukup meyakinkan, $70 \%$ yang menderita alergi terhadap debu, serbuk, jerawat, 
dan asma sembuh setelah diberi minyak Nigella (jintan hitam). Dalam praktiknya, DR. Schleincher memberi resep Nigella ke pasiennya yang menderita influenza. Jadi jintan hitam bisa digunakan sebagai anti histamin.

Penelitian ini diawali dengan menentukan emulgator dan bahan pengental yang aman untuk membuat emulsi oral. Sebelumnya pada tahun 2009, Azwar Dhaniar Ramdhan T telah melakukan penelitian tentang kesesuaian emulgator non ionik dengan kandungan asam lemak minyak dalam menstabilkan emulsi minyak jintan hitam diperoleh bahwa emulgator non ionik yang menghasilkan emulsi yang stabil adalah emulgator tween dan span 60 konsentrasi 3\%. Namun berdasarkan literatur, emulgator non ionik yang aman dan sesuai untuk emulsi oral adalah kombinasi tween dan span 80 . Alasan penggunaan kombinasi emulgator tween dan span adalah untuk menghasilkan emulsi yang lebih stabil. Dan bahan pengental yang aman untuk sediaan emulsi oral adalah gum arab, tragakan, gum xanthan dan Na. CMC. Hal inilah yang menjadi dasar pemilihan emulgator dan kosentrasi emulgator serta bahan pengental yang akan digunakan dalam pembuatan emulsi oral minyak jintan hitam. Untuk meyakinkan hasil penelitian maka dibuat emulsi dengan menggunakan kombinasi emulgator tween dan span 80 serta keempat jenis bahan pengental tersebut. Pada tahap awal pembuatan, emulsi dengan bahan pengental tragakan menunjukan pemisahan fase. Sedangkan emulsi dengan bahan pengental gum arab 18\%, gum xanthan $0,18 \%$ dan $\mathrm{Na}$. CMC $0,8 \%$ tidak menunjukan pemisahan fase. Sehingga ketiga jenis bahan pengental ini dipilih sebagai bahan pengental yang dapat menghasilkan emulsi minyak jintan hitam.

Selain penggunaan minyak jintan hitam sebagai bahan aktif, kombinasi tween dan span 80 sebagai emulgator, gum arab, gum xanthan dan Na. CMC sebagai bahan pengental, bahan-bahan lain yang digunakan dalam formula adalah alfa tokoferol sebagai antioksidan, metil paraben dan propil paraben sebagai pengawet, pasta pandan sebagai pewarna dan pengaroma, dan sukrosa sebagai pemanis. Pengujian kestabilan ketiga jenis formula dengan bahan pengental yang berbeda, dilakukan dengan metode kondisi dipaksakan (stress condition) dengan penyimpanan pada suhu $5^{\circ} \mathrm{C}$ dan $35^{\circ} \mathrm{C}$ selama 10 siklus, masing-masing 
siklus berdurasi 12 jam. Tujuan dilakukannya kondisi dipaksakan adalah untuk mempercepat proses peruraian dari bahan-bahan dan untuk mempersingkat waktu pengujian. Pengujian ini dilakukan dengan beberapa parameter, yaitu :

1. Pemeriksaan organoleptis menunjukan bahwa untuk formula emulsi dengan bahan pengental gum xanthan tidak mengalami perubahan warna, viskositas dan bau baik pada kondisi sebelum maupun setelah dipaksakan. Formula emulsi dengan bahan pengental gum arab tidak mengalami perubahan viskositas dan bau baik pada kondisi sebelum maupun setelah dipaksakan tetapi terjadi perubahan warna setelah kondisi penyimpanan dipercepat. Sedangkan pada formula dengan bahan pengental $\mathrm{Na}$. CMC menunjukan adanya penambahan warna yaitu warna coklat pada saat kondisi setelah penyimpanan dipaksakan, karena terjadi pemisahan fase, dimana lapisan atas berwarna coklat dan lapisan bawah berwarna hijau. Sementara bau dan viskositasnya tidak berubah.

2. Hasil pengujian menggunakan volume kriming menunjukan bahwa emulsi dengan bahan pengental Na. CMC memiliki volume kriming, yang merupakan salah satu gejala ketidakstabilan dari suatu emulsi. Sedangkan emulsi dengan bahan pengental gum arab dan gum xanthan tidak memiliki volume kriming.

Kriming adalah pergerakan ke atas dari fase terdispersi. Hal ini bias disebabkan karena adanya perbedaan jumlah dari kedua fase. Dimana fase yang jumlahnya lebih banyak (fase pendispersi) akan mendesak fase yang lebih sedikit jumlahnya (fase terdispersi), sehingga fase terdispersi ini akan terdorong keluar dari sistem emulsi dan bergerak keatas. Peristiwa inilah yang dinamakan kriming.

3. Penentuan tipe emulsi menunjukan bahwa emulsi minyak jintan hitam dengan bahan pengental gum arab, gum xanthan dan $\mathrm{Na}$. CMC menghasilkan emulsi m/a baik pada kondisi sebelum maupun setelah penyimpanan dipaksakan yang ditandai dengan bergeraknya jarum voltmeter. Tipe emulsi yang terbentuk disebabkan karena jumlah fase air lebih banyak daripada fase minyak.

4. Pengukuran viskositas. Viskositas mempengaruhi kestabilan emulsi 
karena dapat mempengaruhi besarnya laju kriming yang mungkin terjadi, selain itu dapat juga mempengaruhi penggabungan globul-globul. Namun ini hanya berlaku untuk emulsi yang encer. Karena emulsi yang encer tidak mempunyai ketahanan untuk mencegah penggabungan globulglobul. Lain halnya dengan emulsi yang kental.

Hasil analisa statistik RAK (Rancangan Acak Kelompok) terhadap viskositas memperlihatkan tidak adanya perbedaan baik antar formula maupun antar kondisi.

5. Penentuan tipe aliran dari emulsi. Tipe aliran suatu emulsi ditentukan berdasarkan ada atau tidak adanya nilai yield. Nilai yield adalah nilai yang harus dilampaui oleh suatu sediaan untuk bisa mengalir melewati wadahnya. Nilai yield merupakan satu parameter dari beberapa parameter yang mempengaruhi kestabilan suatu emulsi. Nilai yield lebih banyak berhubungan dengan apllikasi dari emulsi. Hubungannya dengan kestabilan terutama hanya dengan tipe aliran yang terbentuk, dimana apabila terjadi perubahan nilai yield berarti mengindikasikan terjadinya perubahan pada tipe emulsi. Perubahan tipe aliran emulsi biasanya menandakan terjadinya ketidakstabilan akibat perubahan susunan atau distribusi dari globulglobul terdispersi dari emulsi.

Hasil analisa statistik RAK (Rancangan Acak Kelompok) terhadap nilai yield memperlihatkan tidak adanya perbedaan baik antar formula maupun antar kondisi.

6. Pengujian yang juga dilakukan adalah analisa ukuran tetes terdispersi. Namun, karena keterbatasan alat maka tidak dapat diukur diameter partikelnya, hanya dapat diamati. Berdasarkan hasil pengamatan, dapat dikatakan bahwa tidak terjadi penggabungan tetes terdesipersi dari emulsi minyak jintan hitam dengan bahan pengental gum xanthan. Sedangkan pada emulsi minyak jintan hitam dengan bahan pengental gum arab dan Na. CMC terjadi penggabungan tetes terdispersi.

Dikatakan bahwa emulsi merupakan suatu sistem yang secara termodinamika tidak stabil. Dikarenakan adanya tegangan permukaan dan tegangan antar muka yang besar antara dua cairan yang tidak saling bercampur. 
Adanya energi bebas permukaan ini, menyebabkan kedua fase dalam sistem emulsi cenderung bergabung antar fase yang sejenis. Penggabungan ini nantinya akan menyebabkan pemisahan fase dalam emulsi. Untuk menghindari hal tersebut, maka salah satu cara yang dilakukan adalah dengan menambahkan bahan yang dapat menurunkan energi bebas dengan cara menurunkan tegangan antar muka dari cairan-cairan tadi. Bahan ini yang disebut dengan emulgator. Namun, karena adanya efek penyimpanan dipercepat yang dilakukan dengan cara menyimpan emulsi pada suhu panas dan dingin, akan menyebabkan emulgator yang berfungsi untuk menstabilkan emulsi tidak dapat bekerja dengan baik lagi. Hal ini akan meningkatkan energi bebas dan tegangan antar muka. Sistem mempunyai cara untuk menstabilkan dirinya dengan cara penggabungan tetes-tetes terdispersi dari fase-fase yang sejenis. Penggabungan inilah yang biasa disebut flokulasi, yang merupakan salah satu gejala ketidakstabilan emulsi.

7. Pada gambar rheogram, emulsi dengan bahan pengental gum arab dan gum xanthan pada kondisi sebelum dan sesudah penyimpanan dipaksakan terlihat kurva yang hampir berimipitan, sedangkan emulsi dengan bahan pengental gum arab dan gum xanthan pada kondisi sebelum dan sesudah penyimpanan dipaksakan terlihat kurva yang tidak berimipitan.

Dari hasil pembahasan tersebut, dapat diketahui bahwa terdapat pengaruh perbedaan bahan pengental yang digunakan terhadap kestabilan emulsi minyak jintan hitam (Nigella sativa) yang meliputi perubahan viskositas dan ukuran tetes terdispersi.

$$
\text { Hasil yang diperoleh }
$$

memperlihatkan bahwa secara organoleptis, formula II tidak mengalami perubahan warna, bau dan konsistensi sedangkan formula I dan formula III terjadi perubahan warna. Pada pengukuran volume kriming formula I dan formula II tidak memiliki volume kriming, sedangkan formula III memiliki volume kriming. Penentuan tipe emulsi menunjukan formula I, II dan III tidak terjadi perubahan sebelum dan sesudah kondisi dipaksakan. Dari hasil perhitungan statistik viskositas dan nilai yield sebelum dan sesudah kondisi dipaksakan untuk formula I, II 
dan III tidak berbeda nyata masingmasing pada taraf $5 \%$ dan $1 \%$. Untuk pengukuran tetes terdispersi, formula II tidak mengalami penggabungan tetes terdispersi, sedangkan formula I dan III mengalami penggabungan tetes terdispersi setelah kondisi penyimpanan dipercepat. Hasil rheogram menunjukan formula I dan II hampir berimpit, sedangkan formula III berjarak jauh. Dari hasil penelitian yang dilakukan diperoleh hasil bahwa bahan pengental yang menghasilkan emulsi yang stabil adalah formula II, yaitu gum xanthan dengan konsentrasi $0,18 \%$.

\section{KESIMPULAN}

Kesimpulan yang diperoleh dari hasil penelitian ini, adalah sebagai berikut bahan pengental yang menghasilkan emulsi yang stabil adalah gum xanthan dengan konsentrasi $0,18 \%$.

\section{DAFTAR PUSTAKA}

Admin., 2007, Penelitian Para Ahli Kedokteran terhadap Habbatus Sauda (Bag 1) (online) (http://www.habbats.com) diakses tanggal 02 Desember 2009.

Anonim., 2007, Khasiat Jinten Hltam (Online), (http://www.medanbisnisonline .com) diakses tanggal 8 November 2009.
Ansel,H.C., 2005, Pengantar Bentuk Sediaan Farmasi, Edisi keempat, penerjemah Farida Ibrahim, Penerbit Universitas Indonesia, Jakarta.
Banker., 1979, Modern Pharmaceutical, Marck Publishing Company, Easton: Pennsylvania.

Direktorat Jenderal POM, 1995, Farmakope Indonesia, Edisi IV, Departemen Kesehatan $\mathrm{RI}$, Jakarta.

Fardiaz.. $\quad 1989 . \quad$ Hidrokoloid. Labolatorium Kimia dan Biokimia Pangan PAU Pangan dan Gizi IPB. Bogor.

Fauzi., 2006, Jintan Hitam Penawar Rasa Sakit dari Timur Tengah (Online), (http ://www.medanbisnisonline.co
m) diakses tanggal 2 Desmber 2009.

Harjono., 2008, Khasiat Jinten Hitam dan Temu Ireng (Online), (http://www.rayakawula.com) diakses tanggal 8 november 2009.

Gennaro, R. Alfonso. 1990. Remington's Pharmaceutical Sciences. Marck Publishing Company, Easton: Pennsylvania.

Jenkins,G.L.,Froukle,D.E.,Brecht,E.A., and Sperandio, G.L., 1957, Scoville's, The Art of Compounding, Ninth Edition, The Blakiston Davison, MC Graw Hill Book Company, inc., New York, Toronto, London.

Kibbe,H.Arthur., 2000, Handbook of Pharmacutical Excipients, 
Three edition, American

Pharmacetutical Press, USA.

Lachman,L.,Liebermen,H.A.,Kanig,J.L. ,1994, The Teory and Practice of Industrial Pharmacy, Third Edition, Lea and Febiger, Philladelphia.

Liebermen., 1996, Pharmaceutical Dosage Form Disperse System volume 1, Second Edition, Marcel Dekker, Inc. New York

Lund., 1994, The Pharmaceutical Codex "Principle and Practice of Pharmaceutics", Twelfth Edition, The Pharmaceutical Press, London.

Martin, A., 1993, Farmasi Fisika, UI Press, Jakarta

$$
\begin{gathered}
\text { Parrot,E.L.,1971, Pharmaceutical } \\
\text { Technology, "Fundamental } \\
\text { Pharmaceutics", Third Edition, } \\
\text { Burgess Publishing Co., } \\
\text { Minneapolis. }
\end{gathered}
$$

Sprowls., 1960, American Pharmacy "Textbook of Pharmaceutical Principles, Processes and Preparation", Lippincott Company, Philadelphia.

Sprowls,J.B.,1978, Prescription Pharmacy, Second Edition, Lippincott Company, Philadelphia.

Voight., R, 1995, Buku Pelajaran Teknologi Farmasi, Gajah Mada University Press, Yogyakarta 